bringing such sources of contagion to the knowledge of those whose duty it is to enforce the law and ordinances designed to suppress them.

Members of boards of education, superintendents, principals and teachers of schools, both public and private, should all be well informed as to the nature of these diseases and the dangers which attend them and their interest and co-operation secured in efforts to check their ravages.

Effective work can be done through church organizations, young peoples' Christian endeavor societies and mothers' meetings.

The young men's and young women's Christian associations are admirable channels for the spread of such knowledge, and the possibilities which the Salvation Army has for reaching these sources of evil directly and effectively must not be overlooked.

In manufacturing, commercial and industrial cities where large numbers of men and women are employed, both young and middle-aged, the interest of employers can usually be enlisted to afford an opportunity for such instruction to be given when it is not possible for these people to be reached through other channels.

In all of this work the physician who knows the facts and can speak from experience must take the lead, and it is in work such as this that the woman physician, of the right sort, will find a sphere of activity and great service peculiarly her own, for separate instruction to the sexes, both young and old, will need to be given plainly, but tactfully, and by those who have seen at close range the dangers they portray and whose word carries conviction because spoken with authority. Broad, disinterested benevolence, such as rightly represents and adds dignity to a liberal profession, should characterize the persons chosen for this work. It is not for the self-seeker nor the unsympathetic, but for those who know what it means to labor for the unperishable riches, and of these workers the medical profession has an abundant share.

In the brief sketch here given I have but presented in outline the plan of campaign already adopted in the state of Michigan. The State Medical Society of that state created, a year ago, a standing committee charged with the duty of bringing to the knowledge of the public the facts that need to be generally known, and referring to the origin, spread and dangers of venereal diseases. This committee was authorized to enlarge its number to twenty, many of whom are chosen from the laity. One most successful meeting has already been held in Detroit, at which it was fully demonstrated that the most influential citizens are quick to respond and follow the lead of the physicians in this work. From this committee of twenty, subcommittees on publication, education and legal enactment have been organized and are at work. On these committees are physicians, lawyers, ministers of several denominations, business men and women devoted to philanthropic and charitable undertakings. There is no question but that which we have demonstrated, through the work of this organization in Michigan, serves but to indicate the general temper throughout America on this most important matter, and it needs no prophet to foresee how fruitful of. good results such a systematic and thorough plan of enlightenment against this grave evil will soon be able to accomplish.

\section{THE DUTY OF THE STATE TOWARD VENEREAL DISEASES.*}

\author{
HENRY D. HOLTON, A.M., M.D. \\ BRATTLEBOBO, VT.
}

In discussing the duty of the state in relation to both syphilis and gonorrhea, we must recognize that, under the present status of public opinion, the state can accomplish very little, either by the enactment of new laws or by giving additional authority to boards of health; that before we seek aid from the state there must be created a public sentiment which will sustain action by authority, but there must also be a strong demand for state interference.

This can only be brought about by an educational movement, which shall begin in the home and continue in the high and preparatory schools and college.

The parents should explain how the race is perpetuated, the sacredness and responsibility of the relations of parents and children, the great moral and physical dangers that attend on the abuse of those functions, and that continence is not incompatible with health. The teacher or physician should enlarge on these lines and point out the diseases that result from impure intercourse; that all clandestine embraces are dangerous, as the individual, male or female, who enters into such relations, be it clandestine or otherwise, will sooner or later become infected; and either of the diseases thus acquired are of the most serious character, of long duration, often followed by the most disastrous results, ending in death or chronic invalidism, and many times by deformity. It is quite possible that the profession should first be educated along the line of duty. Physicians are familiar with the loathsome and disastrous nature of venereal disease; of the danger of its communication to innocent persons; in fact, of the great menace it is to our civilization. Yet in the past we fear that it has been regarded too lightly by some; others have turned away such cases with disgust. In both cases, the great duty of attempting to stay its destruction and progress has not been recognized or at least acted on.

In countries across the sea statistics have been gathered, showing the prevalence, how provided for, and the means used to prevent its spread. In a certain way, these are of value to us, yet the difference of our form of government and social conditions is such as seriously to impair their usefulness when we attempt to draw deductions or to formulate regulations for their control.

The information necessary to carry on successfully the work of prevention should be the first work of any organization that has in view the control of these diseases.

Without going into details it will be recalled that in a joint meeting of this section and that on cutaneous medicine, in 1904, a committee reported on this subject, recommending the sending to every physician a request for certain statistical information, which it was hoped might be useful in the further consideration of this subject.

These communications received the approval of the state and provincial boards of health, and they are here inserted:

- Read In the Section on Hygiene and Sanitary Sclence of the American Medical Association, at the Fifty-seventh Annual Session, June, 1906. 
VERMONT STATE BOARD OF HEALTH.

OFEICE OF THE SECRETARY, BRATTLEBORO.

Dear Doctor:-The enclosed leaflet is issued in the interest of prevention of venereal diseases. It is for you to give each patient who consults you suffering from elther gonorrhea or syphilis. It has been prepared so as to be concise and in language to be understood by everyone. This, we hope, will cause it to be read by those to whom it is handed. It will introduce the subject of prevention, thus enabling you to give your patient further information of the
extent of this scourge. Additional copies of this leaflet can be had on request.

It is estimated thit 80 per cent. of all deaths from pelvic diseases in women are due to gonorrhea. Twenty per cent. of all blindness is due to gonorrheal infection of the newborn. Fifty per cent. of all involuntary chlldless marrlages are caused by gonorrhea of the female organs of generation, of which 45 per cent are due to marital infection by men. In this country it is impossible to quote statistics, as they never have been gathered. The committee of fifteen estimated that there were annually 200,000 cases in New York City alone. In Prussia, where they have more reliable data, it has been stated that typhoid fever represents a yearly loss of $8,000,000$ marks, while the increased expenses and decreased income caused by venereal diseases amount to $90,000,000$ marks annually, an amount which exceeds that caused by tuberculosis. But the financial loss is of minor Importance compared with the enormous soclal changes and consequent social misery.

In riew of these startling facts, which indicate the Increasing danger to our people, will you not, my dear doctor, aid your state board of health in gaining reliable statistics relative to these diseases, by returning to the secretary each year the following blank with every question answered?

Cases of gonorrhea observed during the year $190 \ldots$ Male.... Female... Marrled.... Single... Number having chlldren.... Number without children.... . Fe Cases of syphilis.... Male.... Female.... Married... Single

CIRCULAR OF INFORMATION ADOPTED BY THE CONFERENCE OF STATE AND PROVINCIAL BOARDS OW HEALTH OF NORTH AMERICA.

Issued by the State Board of Health of Vermont.

We hand you this leaflet believing that you would not willingly communicate your disease to some Innocent person.

Many fail to comprehend the exceedingly disastrous results that often follow these diseases. Many cases of blindn resure disability, and not infreques. rhea ts one of the most frequent rea is one of the most frequent causes of diseases pecullar to public health that the medical have these diseases become to the countries have become alarmed; and are advocating measures for their prevention.

Syphilis (or pox) is especially a disease from which innocent persons may suffer, as It usually produces sores in the mouth or on the lips, hence may be conveyed by kissing, drinking from the same cup, or using anything which has been put to the lips or into the mouth of one affected by the disease.

These diseases are often communicated when the patlent thinks he has recovered. Hence marriages contracted at this time of the disease result in much unhappiness, and often in the death of the wife. To protect yourself and others, we earnestly advise the following.

IN THE INTEREST OF PREVENTION OF YOJR DISGASE.

What to do and what not to do, to get well and to prevent giving your disease to any other person.

Follow strictly the advice of your doctor, use no other treatment. Iemember that it takes a long time to entirely recover.

Carefully wash your bands with soap and hot water whenever you handle the private parts.

Do not have intercourse and avold all sexual excitement untll your physician says you are completely cured. Be especlally careful not to rub your eyes with your fingers.

Do not allow any person to use any cup, glass, spoon, fork or anything that jou have put in your mouth.

Do not kiss anyone or wipe the face of a chlld with a handkerchlef you have used. Always use a separate towel. Burn all cloths or cotton soiled by discharges.

It was then considered desirable to send the circular of information to the principals of preparatory schools and to the presidents of all colleges, with a request that they call the attention of their medical officer to the subject, to the end that it should be presented to the students in their respective institutions. The committee not having funds to defray the expenses of printing and postage, applied to the trustees of this Association, asking that the printing office of the Association aid them, but were refused this assistance. So far as we are informed, these circulars have only been sent out in Ohio, Florida, Minnesota and Vermont.

If all cases were reported to boards of health as other communicable diseases are (without names), so that we could arrive at a fairly accurate estimate of the whole number of cases occurring, the number of each, the manner acquired-whether innocently or otherwise--and the effects on procreation, we should have a foundation on which to base recommendations for prevention. A more accurate recognition and division of the manner of communication, whether from the ordinary courtesan, clandestine embrace, or from entirely innocent sources, is also of importance.

\section{THE WAR AGAINST THE VENEREAL DIS- FASES IN FRANCE.* \\ THEODORE TUFFIER, M.D.}

Professor Agrege of the Faculty of Mediclne of Paris; Surgeon to the Hospital Beanjou,

PARIS, FRANCE.

The question of venereal prophylaxis is the order of the day in our country; from all sides medical men, statesmen and even literary men are combining their efforts to contend against this scourge. New measures are being studied and our Société de Prophylaxie, composed of internalists, surgeons, obstetricians, the most eminent members of the school of law and the principal police officials, meets once a month to consider important matters relative to the subject. This society has been productive of definite results.

The system in use in France is composed of two separate branches-absolutely different-that is, the police and the medical service. Government surveillance is exercised in reference to houses of prostitution as well as to the so-called free prostitutes who are registered at police headquarters. The inmates of all houses are examined once a week, the others are obliged to report to the examiner once in two weeks. $A$ card is given them which shows the absence of every venereal symptom at this visit, and is in effect an authorization to continue their calling. There is also clandestine prostitution, the object of special consideration by thie police, which constitutes, strange to say, a third of all diseased women. When arrested, these women are kept in a special hospital-Saint Lazar-until cured.

This system which has been in existence for numerous years is now violently attacked. It is said that an examination made so infrequently is necessarily illusory as regards any benefit. It is claimed that prostitution should be free. The dictum has gone forth: "A free woman on a free sidewalk." The abolitionists in France are represented chiefly by an extraparliamentary constituency. Everybody believes that the system should be modified, and various modifications are being studied.

\section{ACTIVE FORCES IN THIS WORK.}

Among the most active forces in the study of this prophylaxis and the practical methods best adapted for its realization must be mentioned the collaboration of Professor Fournier, the world-renowned syphilographer, and Mr. Brieux, a dramatic writer of great talent. They have already done much for the cause, one by his authoritative writings and the other by his theatrical representations, of which "Les Avariés" has achieved a universal recognition. Their program is this: To tell everybody regarding the existence and the danger of syphilis and to increase the facilities for treatment. The education of the people regarding venereal matters is effected by an active propaganda. A series of conferences is established wherever men are grouped together. In the army and navy this is done officially by the medical officers. In great industrial centers, which are the hot-beds of syphilitic propagation, instruction is given

* Translated by Denslow Lewis, M.D., Chlcago.

- Read In the Section on Hygiene and Sanitary Sclence of the American Medical Association, at the Fifty-seventh Annual Session, June, 1906. 